\title{
EFFECT OF "SITTAMATTI (SIDA CORDIFOLIA LINN.) KUDINEER (DECOCTION)" IN RESPIRATORY COMPLAINT - COUGH
}

\author{
Dr. S. R. Pholtan Rajeev ${ }^{*}{ }^{\natural}$ \\ ${ }^{* 1}$ Ayurvedic Medical Officer, Department of Indigenous Medicine, Eastern Province, Sri Lanka
}

DOI: https://doi.org/10.29121/granthaalayah.v8.i8.2020.707

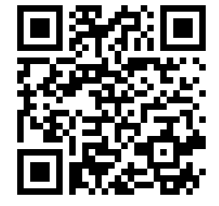

Article Type: Research Article

Article Citation: Dr. S. R. Pholtan Rajeev. (2020). EFFECT OF

"SITTAMATTI (SIDA CORDIFOLIA LINN.) KUDINEER (DECOCTION)" IN RESPIRATORY COMPLAINT COUGH. International Journal of Research -GRANTHAALAYAH, 8(8), 24-36.

https://doi.org/10.29121/granthaa layah.v8.i8.2020.707

Received Date: 10 July 2020

Accepted Date: 18 August 2020

Keywords:

Sida Cordifolia Linn

Kudineer (Decoction)

Cough

Ayurveda

Siddha

\section{ABSTRACT}

Background: The world is fulfilled by various medicinal plants which are widely have been used in treatment of various diseases since ancient time. Medicinal plants still play an important role in emerging and developing countries. Herbs are staging a comeback and herbal 'renaissance' is happening all over the globe. The herbal products today symbolize safety in contrast to the synthetics that are regarded as unsafe to human and environment. Although herbs had been priced for their medicinal, flavoring and aromatic qualities. In this research, sittamatti (Sida cordifolia) has been reported to possess analgesic, anti-inflammatory and hypoglycemic activities as well as hepato-protective activity. Traditionally the plant Sida cordifolia (Linn) has been used as CNS depressant, fat lose, analgesics, anti-inflammatory, hypotensive, hepato protective. Presence of ephedrine has highlighted the utility of this plant. various Ayurvedic preparation of this plant used in asthma diseases, etc.

Methods: This plant spread in Mullaitivu commonly therefore utilize that as Cough decoction. First authentication of plant with experts from University of Jaffna and collecting, washing, drying and grinded for decoction preparation size. Then packing and labeling and distribute to selected 60 research samples of two groups to clinical trial and collected data through questionnaire and result analyzing in statistical way.

Result: Group-I \& Group-II 1st Week (AFTER treatment) level of the samples.

The test is significant at 0.0001 (adjusted for ties) Comparing the HT (Group-I), Research Decoction (Group-II) was shown Significant $(\mathrm{p}<0.05)$ reduction in symptom of cough. One-month (04 Weeks) of treatment with research decoction significantly $(\mathrm{p}<0.05)$ change symptom of cough with the control group- hospital internal treatment (HT) (group-I).

Conclusion: effectiveness of research drugs - Sittamati Kudineer, Three months (04 Weeks) of treatment with research decoction significantly $(\mathrm{p}<0.05)$ change symptom of cough with the control groupnormal hospital internal treatment (HT) (group-I). 
Dr. S. R. Pholtan Rajeev

\section{INTRODUCTION}

According to the world health organization, herbal medicines are being used by about $80 \%$ of the world population primarily in the developing countries for primary health care. This plant-based traditional medicinal system continues to play an essential role in health care. Sida corifolia (linn) syn. Country Mallow of Malvaceae family is widely distributed along with other species are common throughout the tropical and sub tropical plains all over India and Srilanka up to an altitude of $1050 \mathrm{~m}$., growing wild along the roadside. It grows as wasteland weed. It is also known as the "Bala" in Hindi and Sanskrit. (Narayan et al., 1956) The plant name Bala is coined on the name of 'Parvati' (goddess of strength and beauty). The quantities are low, with less than 2\% of ephedrine and pseudoephedrine found in the leaves of Sida cordifolia. Ephedrine is known to stimulate the central nervous system (CNS), and as such can enhance weight loss. Traditionally nutrition companies used plants such as Ma-Huang (Ephedra plant), because it contained relatively large amounts of ephedrine, in their weight loss products. However, since this product was banned in many countries including the USA and UK, they are now looking for alternatives. Sida cordifolia, with its ephedrine and pseudoephedrine has gained a lot of interest and is now sold by many of these companies (Ghosal et al., 1975).

Sida cordifolia is a small, erect, downy shrub. The leaves of the plant are chordate-oblong or ovate- oblong and fruits with a pair of awns on each carpel. Roots of the plant which constitute a drug are 5-15 cm long with few lateral roots of smaller size. The tap roots are generally branched at the tip. The outer surface of the root is off to grayish yellow. It is almost odourless with slightly bitter taste (Rangari et al., 1995). The present review highlights the contribution of Sida cordifolia in modern system of herbal medicine for new drug development. There is correlation established between the active constituents and their uses in different diseases. Some Ayurvedic preparation and supplement of plant available in market are also mention.

The plant Sida cordifolia L., the plant grows well throughout the plains of India and Sri Lanka especially is damp climates. The shrub grows up to $0.75-1.5 \mathrm{~m}$ in height. The roots and the stem being stout and strong. The leaves are 2.5-7 cm and 2.5-5 cm broad with 7-9 veins. They are heart shaped, serrate and truncate. The flowers are small. Yellow or white in colour, solitary and auxiliary. The fruits are a moon-sized, 6-8 $\mathrm{mm}$ in diameter. The seeds are called as bijabanda in Ayurveda, are greyish black in colour and smooth. The flowers blossoming from August to December and fruiting occurs from October to January. It was observed that ethanol and methanol extract of the leaves of Sida cordifolia L.

The both extracts were showed that the presence of alkaloids, glycolysides, carbohydrates, flavonoids, phenols, saponins and tannins. It was observed that ethanol and methanol extract of good inhibitory action against all the selected bacteria except Escherichia coli. The present findings showed that ethanol extract was more effective than methanol extract against all the selected bacteria. It is concluded that ethanol and methanol extract of Sida cordifolia L. can be effectively used in curing the bacterial diseases such as treat as variety of health disorders like bronchial asthma, cold and flu, chills, lack or perspiration, headache, nasal congestion-aching joints and bones, cough, wheezing, edema and keeping the good health of the people.

\section{MATERIALS AND METHODS}

\subsection{PLANT MATERIAL COLLECTION, AUTHENTICATION AND GARBLING PROCESS}

The plant material is whole plant of Sida cordifolia L. were collected in sufficient quantities from the natural habitats from the bare land of Mulliyawalai area in Mullaitivu district, Northern part of Sri Lanka. The collected whole plants were shade-dried at room temperature into small pieces for preparing decoction packs. The plant Voucher No. DAH/Mul/01. The plant authenticated by Dr. (Mrs.).V. Sathiyaseelan. Senior Lecturer and Head of Material Medica Section, Unit of Siddha Medicine, University of Jaffna and Ms. Sudeepa Sugathadasa. In-Charge Scientist (Pharmacognosy), Botany section, Bandaraneke Memorial Ayurvedic Research Institute (BMARI), Colombo, Sri Lanka. 


\title{
2.2. BOTANICAL DESCRIPTION
}

Sida cordifolia grows well through the plains of India, especially, in damp climates. The shrub grows up to 0.75 -1.5 meters in height. The root and the stem are stout and strong. The leaves are $2.5-7 \mathrm{~cm}$ long and $2.5-5 \mathrm{~cm}$ broad, with 7-9 veins. They are heart shaped, serrate and truncate. The flowers are small, yellow or white in colour, solitary and axillaries. The fruits are moong-sized, 6-8 mm in diameter. The seeds are called as Bijabanda in Ayurveda, are grayish black in colour and smooth. The plant flowers from August to December and fruiting occurs from October to January (Pole et al., 2006).

Sida cordifolia Linn is a herb belonging to the family Malvaceae (Sutradhar et al.,2006). This plant is used in folk medicine for the treatment of stomatitis, blenorrhea, asthmatic bronchitis, and nasal congestion (Balbach, 1978).

\subsection{VERNACULAR NAMES}

Hindi - Kungyi, English - Country mallow, Sanskrit - Bala, Tamil - Sittamati, Bengali - Brela, Guajarati Junglimethi, Malayalam - Velluram, Punjab - Simak, Maharastra - Chikana (Ankit Jain et al., 2011)

\subsection{SCIENTIFIC CLASSIFICATION}

\author{
Kingdom - Plantae \\ Division - Angiospermae \\ Class - Eudicots \\ Order - Malvales \\ Family - Malvaceae \\ Genus - Sida \\ Species - Sida cordifolia (Ankit Jain et al., 2011)
}

Regional Names: Bariar, Batyalaka, Beejband, Bijband, Brela, Chikana, Chiribenda, Chitimutti, Hettuti-gida, Janglimethi, Kharenti, Khareti, Kisangi, Kungyi, Mayir-manikham, Muttuva, Paniyar-tutti, Simak, Tupkaria, Tutturabenda and Velluram. (Ankit Jain et al., 2011)

\subsection{OCCURRENCE AND DISTRIBUTION}

Country Mallow of Malvaceae family is widely distributed along with other species are common throughout the tropical and sub-tropical plains all over India and Sri Lanka up to an altitude of $1050 \mathrm{~m}$., growing wild along the roadside. (Ankit Jain et al., 2011)

Part Used: Seed, Leaves, Roots

Macroscopic Characters

Stems - stout and strong

Leaves $-2.5-7 \mathrm{~cm}$ long and $2.5-5 \mathrm{~cm}$ broad, with 7-9 veins.

Flowers - small, yellow or white in colour, solitary and axillaries.

Fruits - moong-sized, 6-8 $\mathrm{mm}$ in diameter

Seeds - grayish black in colour and smooth.

\subsection{CHEMICAL CONSTITUENTS}

Ephedrine., Pseudoephedrine, Sterculic, malvalic and coronaric acid, Fatty acids, Saponine, Betaphenethylamine, Hypaphorine, Ecdysterone, Indole alkaloids, Palmitic, stearic and $\beta$ - sitosterol.

Malvaceae, commonly known as Bala, is an Ayurvedic medicine that is used to treat bronchial asthma, cold and flu, chills, lack of perspiration, head ache, nasal congestion, aching joints and bones, cough and wheezing, and edema. The root infusion is given in nervous and urinary diseases and also in disorders of the blood and bile. Sida cordifolia has been reported to possess analgesic, anti-inflammatory and hypoglycemic activities as well as hepato protective 
activity. Traditionally the plant Sida cordifolia (Linn) has been used as CNS depressant, fat lose, analgesics, antiinflammatory, hypotensive, hepato protective. Presence of ephedrine has highlighted the utility of this plant. various Ayurvedic preparation of this plant used in asthma diseases, fat lose and increase energy, Oil preparation is also cure pain, swelling disorder, and Gritha cures Heart diseases. This plant has great potential to develop the Ayurvedic, modern medicine and athletic supplements by pharmaceutical industries. The present review is highlights the traditional uses, Ayurvedic preparation, chemical constituents and pharmacological properties of Sida cordifolia (linn) syn. Country Mallow. (Ankit Jain et al., 2011)

\subsection{THERAPEUTIC USES}

The Plant is alternative tonic, astringent, emollient, aphrodisiac etc.

Bark - Considered as cooling. It is useful in blood, throat, urinary system related troubles, piles, phthisis, insanity etc.

Seeds- The seeds as considered as aphrodisiac.

Roots -It is regarded as cooling, astringent, stomachic and tonic, aromatic, bitter, diuretic. (Ankit Jain et al., 2011)

\subsection{SIDA CORDIFOLIA PHYSIOLOGICAL EFFECT}

It has a depressant rather than a stimulant effect on the Central Nervous System

May decrease both blood pressure and heart rate

It has a hypoglycemic (blood sugar lowering effect)

No real evidence to support its use as a weight loss supplement

Increases pain tolerance

It has an anti-inflammatory effect

possible antioxidant effect (Ankit Jain et al., 2011)

\subsection{SIDE EFFECTS}

Sida cordifolia when used excessively can cause ephedrine related side effects like insomnia, anxiety, nervousness, and increase in blood pressure, memory loss or even stroke.

Ephedrine coupled with caffeine can prove fatal. Patients subjected to IOC drug testing, using MAO inhibitor medication (Antidepressants), having high blood pressure, heart disease, thyroid or prostrate condition along with pregnant or lactating women should not take this herb except under expert guidance. (Ankit Jain et al., 2011)

\subsection{TRADITIONAL USES}

It has a long history of use by Ayurveda and rural area particularly for medicinal properties. It is in use as folk medicine in India since time immemorial. According to Ayurveda, the plant is tonic, astringent, emollient, aphrodisiac and useful in treatment of respiratory system related troubles. Bark is considered as cooling.

It is useful in blood, throat, urinary system related troubles, piles, phthisis, insanity etc. (Agharkar et al., 1991).

The plant is analgesic, anti-inflammatory and tonic. It affects the central nervous system and provides relief from anxiety. Its extract is consumed to reduce body weight. It tones the blood pressure and improves the cardiac irregularity. It is also useful in fever, fits, Ophthalmic, rheumatism, colic and nervous disorders. It has also been reported to improve sexual strength. Sida cordifolia oils are used topically to the sore muscles and sore joints in rheumatism and arthritis with the crushed leaves can be carried out a cataplasm to alleviate local pains and because of its astringent value for the cure of external wounds or imperfections of the skin.

The bronchodilator value of the vasicinone, vasicine and vasicinol are used to elaborate preparations for the treatment of the bronchial affections, especially in what refers to the cough, asthma, bronchitis, nasal congestion, flu, pain in the chest, etc. Decoction of the root of bala and ginger is given in intermittent fever attended with cold shivering fits. Root juice is also used to promote healing of wounds. Powder of the root and bark together, is given with milk and sugar for frequent micturition. Oil prepared from the decoction of root bark mixed with milk and sesame oil, finds application in diseases of the nervous system, and is very efficacious in curing facial paralysis and 


\section{Effect of "Sittamatti (Sida Cordifolia Linn.) Kudineer (Decoction)" in Respiratory Complaint - Cough}

sciatica (koman et al., 1921). According to Ayurveda 'Bala' balance all the doshas - vata, pitta, kapha. It has more effect on vata dosha. Leaves are cooked and eaten in cases of bleeding piles. Juice of the whole plant, pounded with a little water is given in doses of $1 / 4$ seers for spermatorrohea, rheumatism, and gonorrhoea. Made into paste with juice of Palmyra tree, it is applied locally, in elephantiasis (Yogaratnakaram).

\section{PHARMACOLOGICAL ACTIVITIES}

CNS depressant: Franco et al tested that rather than being a stimulant, Sida cordifolia actually acts as a depressant and decreases CNS activity. (Franco et al., 2005) Medeiros et al, Additional research appears to confirm that Sida cordifolia does not stimulate the CNS (Mediros et al., 2005).

Fat lose: Medeiros et al studied, the oral consumption of S.cordifolia by rats actually caused a decrease in both heart rate and blood pressure. (Mediros et al., 2005), However safeties of S.cordifolia extract will be always objectionable on basis of:

1. Appetite suppression and cardiovascular effects as these are associated with ephedrine.

2. The only support of Sida cordifolia as a weight loss product is through its hypoglycemic (blood sugar lowering) activity.

Research studies have shown that it possesses a significant blood sugar lowering activity and therefore may help to reduce the storage of fat with fat cells (Kanth et al., 1999).

Analgesic and anti-inflammatory: Kanth and Diwan also demonstrated that $S$. cordifolia can increase pain tolerance and appears to have anti-inflammatory properties. (Kanth et al., 1999) When rats were exposed to heat, rats that consumed Sida cordifolia had a greater heat tolerance. It may be effective as an antioxidant (Auddy et al., 2003). Diwan and Kulkarni studied anti-inflammatory activity of ethyl acetate and alcohol extracts of S.cordifolia was studied in rats.The percent inhibition of oedema was calculated with reference to the control group. The aerial part exhibited significant anti-inflammatory activity only at a dose level of $600 \mathrm{mg} / \mathrm{kg}$. Both Sida cordifolia aerial and root extract showed dose dependent activity (Diwan et al., 1983). V Ravi Kant tested Acetic acid induced writhing test method on Analgesic activities. Increase of latency time in relation to the control was taken as an index of analgesic activity (Kanth et al., 1999).

Hypotensive: Medeiros et al performed the aqueous fraction of hydro alcoholic extract of S. cordifolia induced hypotension and bradycardia on mean arterial pressure and heart rate in nonanaesthetized rat.( Eddy et al ., 1953) Administration of atropine completely abolish the Aqueous fraction of hydro alcoholic extract of S.cordifolia induced hypotensive and bradycardic responses. (Mediros et al., 2005).

Hepatoprotective: Fumaric acid isolated from S.cordifolia was reported to be hepatoprotective (Kumar et al., 1997). Recent works has reported hepatoprotective effect of aqueous extract of $S$. cordifolia after partial hepatectomy (Silva et al., 2006). Silva investigated that Sida cordifolia stimulates insulin release by pancreatic â cells, acting like sulphonylureas. (silva et al., 2008)

Anti-microbial activity: Mahesh et al reported that $S$. cordifolia leaf extract showed highest antibacterial activity against $F$. verticillioides. (Mahesh et al., 2008).

Anti-Parkinson's disease: Massage therapy, enema, medication methods are applied. In addition to Mucuna pruriens (known by names violet bean, cowhage, naikkurana and kaunch beej), Ashwaganda (Withania somnifera), Sida cordifolia are the prime herbs usable in Parkinson's disease Ayurvedic treatment. (Dev seri et al., 2008)

Wound healing activity: Jaiswal studied that plant used in wound healing activity. (Jaiswal et al., 2004)

Anti-Hyper triglyceridemic activity: The antihypertriglyceridemic potential of $S$. rhomboidea. Roxb leaf extract mediated via decreased intestinal absorption and increased catabolism of TG. Pharmacological evidence for use of sida leaf extract as a folklore medicine for controlling obesity amongst north-eastern population of Indian subcontinent.

Table 1: Phyto constituents of different parts of "Sida cordifolia" plant with \% alkaloids

\begin{tabular}{|c|c|c|}
\hline Plant parts & Phyto-constituents & $\begin{array}{c}\text { Alkaloids } \\
\text { percent }\end{array}$ \\
\hline $\begin{array}{c}\text { Whole parts (include } \\
\text { leaves, stems, seeds } \\
\text { and roots) }\end{array}$ & Large amount of ephedrine & Extend of \\
& & $0.085 \%$ \\
\hline
\end{tabular}


Dr. S. R. Pholtan Rajeev

\begin{tabular}{|c|c|c|}
\hline Seeds & Sterculic, malvalic and coronaric acid along with other fatty acids. & $0.32 \%$ \\
\hline Leaves & Ephedrine, pseudoephedrine & $0.28 \%$ \\
\hline Stems & Ephedrine & $0.22 \%$ \\
\hline Roots & $\begin{array}{c}\text { Ephedrine, saponine, choline pseudoephedrine, betaphenethylamine, } \\
\text { vasicine, hypaphorine, ecdysterone and related indole alkaloides. }\end{array}$ & $0.06 \%$ \\
\hline Aerial parts & $\begin{array}{c}\text { Ephedrine, pseudoephedrine, Palmitic, stearic and } \beta \text { - sitosterol, } \\
\text { hexacosanoic acids, 6-phenyl ethyl amine, carboxylated tryptomines, } \\
\text { qunazoline, hypaphorine, vasicinol }\end{array}$ & $0.31 \%$ \\
\hline
\end{tabular}

Journal of Applied Pharmaceutical Science 01 (02); 2011: 23-31

Hypoglycemic activity: Sida cordifolia use as a weight loss product is through its hypoglycaemic (blood sugar lowering) activity. Research studies have shown that it possesses a significant blood-sugar lowering activity and therefore may help to reduce the storage of fat with fat cells. (Chopra et al., 1956)

Anti -oxidant activity: Dhalwal et al studied that all extracts of Sida cordifolia. have effective reducing power and free-radical scavenging activity. (Dhalwal et al., 1983).

Other uses: The roots of S.cardifolia have been reported to possess astringent, diuretic and tonic properties. The drug has also demonstrated antibacterial, antiplaque and antifungal activities.

\subsection{SIDA CORDIFOLIA EPHEDRINE ACTIVITY}

Sida cordifolia leaves contain small quantities of both ephedrine and pseudo-ephidrine. However, the quantities are low, with less than $2 \%$ of ephedrine and pseudoephedrine found in the leaves of Sida cordifolia. Ephedrine is known to stimulate the central nervous system (CNS), and as such can enhance weight loss. Traditionally nutrition companies used plants such as Ma-Huang (Ephedra plant), because it contained relatively large amounts of ephedrine, in their weight loss products. Ephedrine, a 2-aminophenylpropane alkaloid was first isolated from Ephedra sinica Stapf. (Ma-Huang). Ephedra gerardiana. Wall. ex Stapf. is widely used in Ayurvedic system of medicine.

Ephedrine is a potent bronchodilator. Another alkaloid reported form Ephedra sp. is pseudoephederine which seems to be present in lower concentrations in Sida cordifolia. Ephedrine and nor ephedrine suppresses the appetite resulting in weight loss. Other alkaloids like nor-pseudoephedrine are less potent as compared to ephedrine and norephedrine (also known as phenylpropanolamine) and can cause serous ill effects. Therapy with nor ephedrine has been linked with stroke in young age group. Food drug administration has restricted the use of nor-ephedrine in States. Here it is not worthwhile to mention that nor is ephedrine used in common cold preparations also. (Ghosal et al., 1975)

\subsection{STRUCTURE OF EPHEDRINE}

Ephedrine content of Sida cordifolia is less as compared to Ephedra sinica. This suggests feeble analeptic and central nervous system stimulating effects of Sida cordifolia. However, Sida cordifolia contains other bronchodilator alkaloids like vasicinone, vasicine and vasicinol which are absent in Ephedra sinica. In terms of presence of alkaloids like vasicinone, vasicine and vasicinol, Sida cordifolia resembles with Adhatoda vasica Nees. N.O.: Acanthaceae. Ayurvedic formulations containing Sida cordifolia should not be prescribed with cardiac glycosides, monoamine oxidase inhibitors and ergot alkaloids (Chopra et al., 1982). Although no drug interactions have been reported with Sida cordifolia preparations but owing to great variation of active constituent, great care should be taken while prescribing Sida cordifolia with cardiac glycosides (can cause disturbance of heart rhythm), monoamine oxidase inhibitors (as it can potentate the symapthomimetic activity) and ergot alkaloids (can cause hypertension).

Although little data is available on active constituent of Sida cordifolia but according to one study a minute dose of Sida cordifolia given intravenously, causes a sharp and well marked rise of blood pressure in anaesthetized or decerebrated animals which is maintained for some time. This pharmacological activity of Sida cordifolia resembles with ephedrine. According to Mark Blumenthal effects of ephedrine should not be confused with Ephedra sinica. This is a typical example of difference in pharmacological activities of whole herb and isolated constituents. Similar concept applies when we compare Sida cordifolia with ephedrine. (Singh et al., 2006) 


\section{AYURVEDIC PREPARATIONS}

Externally used preparation: the medicated oil of bala, Bala siddha taila, is massaged to alleviate pain and swelling in vata disorders. The paste of its leaves is applied in ophthalmic diseases and for wound dressing. In children, the famous oil preparation of bala - Candan bala laksadi taila is used for massage in muscular weakness.

In siddha medicine, sittamatti prepared drugs are, sittamatti mudakku thailam, sittamati thailam also present and treated to patients. (Ankit Jain et al., 2011)

Internally used preparation: Internally, bala is the best nervine tonic and rasayana for all kinds of vata disorders. It is also rejuvenative, nutritive and stimulant to the heart. As a milk decoction with sugar, it is a good nutritive and aphrodisiac. It also promotes healing of tissue in chronic infectious diseases. In particular, it is highly recommended in extensive tuberculosis with cavitation. For that the decoction of its roots works well, when given with ghee and honey. It promotes the healing of lung tissue and curbs the cavitation. Bala is a valuable blood purifier helpful in raktapitta and piles. It is especially anabolic to muscle tissue and augments the seminal fluids, and promotes reproduction. As it helps building the muscle tissue, it boosts the strength and hence, imparts a rejuvenate action. As a tonic, it is commonly used in general debility. In menorrhagia it is salutary as it is styptic as well as blood purifier. It also boosts the foetal growth. Bala mula siddha dugdha- the medicated milk of bala heals the ulcers and wounds of urinary tract, alleviate bleeding in urine and relieves dysuria. In vata disorders like paralysis, facial palsy, cervical spondylosis etc. Bala works well as a nervine tonic. N such conditions, the decoction of its roots given orally and bala siddha taila - its mediacted oil is used for massage. Bala oil can be used orally, externally for massage and for giving enema (basti) also. The fresh juice of whole plant is recommended for raktapitta bleeding disorders, along with the milk and rock candy (ayurvedic.com).

\subsection{CLASSICAL AYURVEDIC PREPARATIONS} 2011)

Bala taila, Satapakiksirabala, Bala curna / swarasa, Baladya ghrta, Baladyarista, Baladi kvatha (Ankit Jain et al.,

Candana balalaksadi taila: Externally, the medicated oil of bala, Bala siddha taila, is massaged to alleviate pain and swelling in vata disorders. In children, the famous oil preparation of bala, Candan bala laksadi taila is used for massage in muscular weakness. Bala mula siddha dugdha- the medicated milk of bala heals the ulcers and wounds of urinary tract, alleviate bleeding in urine and relieves dysuria (www.herbcureindia.com). The popular Mahanarayana taila, Balati taila, Prabhanjana Vimardhana, Ksheera-bala taila contain this herb. The oils are used topically to massage the sore muscles, sore joints in arthritis and rheumatism, in sciatica and neuritis of legs. Another oil called Dhanvantari tailam (21 and 101 times boiled) which contains Bala along with 47 other substances, Baladhyam Gritham, Yakshmani. This gritha is given for the following diseases: fever, T.B, bronchitis, headache, and migraine. Chakrapani Datta recommended that this gritha can be consumed by adding two parts of milk to it (Koman et al 1921).

Baladhyam Gritham, Urakshathe: This Gritha cures Heart diseases, colic, bronchitis and vata-pitta doshas. Ayurvedic formulations containing Sida cordifolia should not be prescribed with cardiac glycosides, monoamine oxidase inhibitors (Dawson et al., 1995).

Supplements of $\boldsymbol{S}$. cordifolia: These are the strongest Sida cordifolia health supplement currently on the market:-

1) Sida Cordifolia $400 \mathrm{mg}$ of a 4:1 Extract (1600 mg) 60 Capsules-1-2 capsules per day can help you to take advantage of the many health benefits provided by the Sida Cordifolia herb: -

- may enable super-charged workout

- may help fat burning and weight.

- may increase energy, concentration and focus.

- may provide respiratory relief from asthma and bronchitis.

- may provide Joint pain anti-inflammatory relief.

2) Garnell sida cordifolia - 90 vegicaps

3) Cnp sida cordifolia 120 tablets 
4) Reflex Sida cordifolia complex Sida cordifolia complex is a herbal complex designed to trigger fast fat loss. It contains precise ratio of sida cordifolia (10\% alkaloids) Gurana (22\% caffeine) and white willow bark (20\% salicin) to trigger thermogenesis (fat loss).

5) Sida cordifolia slimming pills.

6) Chocolate banana sida cordifolia $1600 \mathrm{mg}$.

7) Sida Cordifolia 120 Tablets CNP Nutritional Supplements. (Ankit Jain et al., 2011)

\subsection{MARKETED PREPARATION}

Baladhyam Gritham -

According to Ayurveda 'Bala' balances all the doshas - vata, pitta, kapha. It has more effect on vata dosha.

Valatitikta madhura pittatisaranasani

Valaviryaprada pustikapharogavisodhani

typical preparations and dosage of bala / sida cordifolia. (Ankit Jain et al., 2011)

\subsection{SUGGESTED DOSAGE}

1) Bala fair trade Powder -Take 1/2 to 2 grams per day, use mixed with milk or fruit juice. (Can be split up over day)

2) Bala / Sida cordifolia Fair trade Tincture - Extraction Ratio 1:3 Alcohol vol. 25\% 5-10ml daily (can be split up into 2-3 doses per day) or as directed by an herbal practitioner. (Ankit Jain et al., 2011)

\section{PREPARATION OF PLANT DECOCTION PACK}

Fully dried raw material packed with sterile condition with transference polythene. Each pack has $30 \mathrm{~g}$ weight of dry chopped Sittamatti whole plants.

Pack has patients' instructions also.

\section{CLINICAL STUDY}

\section{Respiratory symptom - cough measures;}

- Periods per day

- Productive or none productive (sputum)

- Continue / intermitted

- Associated symptoms

Difficult to breath, Fever, Chest pain, Headache

\section{Exclusive criteria}

- $\quad$ Server fever, Tuberculosis (TB), COPD, Pneumonia, Bronchial Asthma for more than 02 years, Cardiac Asthma / Renal Asthma, Smokers, Ischemic Heart Disease (IHD), Communicable diseases, Pregnant / Lactating Mothers, Debilitate diseases, medication for other systemic diseases or metabolic diseases, psychiatric patients.

1) Identify the literature in Siddha Pharmacopoeia.

2) Collecting with authentication and standardization.

3) Making the final product of the Siddha drug (decoction pack).

4) Clinical test for the drug from 60 patients in OPD (Out Patient Department) and data collecting from a suitable Pro forma.

5) Assessment Criteria and analysis. 


\section{Final Assessment Criteria}
1) Cured.
2) Marked improvement.
3) Moderate improvement.
4) Mild improvement.
5) Very mild.
6) Not improvement.
7) Aggressive.

Analysis of the data and making the thesis - Qualitative statistical analysis Grouping the Samples:

In this research, total sample divided into two (02) groups but all are same symptom- cough condition. Those two groups are given below;

Group I: Hospital internal treatment (HT) (30 patients)

Group II: Research decoction with Hospital internal treatment (HT) (30 patients)

\section{CLINICAL STUDY}

Sittamatti kudineer (decoction) pack (30g) prescribed for both Groups (I, II) and advice to patient for avoid Coffee during medication. And each weeks analysis with clinical assessments of respiratory complaints, especially cough.

Hospital Treatment (H.T) is as follows:

\begin{tabular}{|l|l|l|}
\hline Medicine & Dosage Period of intake & Vehicle (Anupanam) \\
\hline Thalisadi Choornam & 30 grains Thrice a day & With Bee's honey \\
\hline
\end{tabular}

Research drug prescribed for selected sample group -II and studied under the decoction pack boiled and drink $120 \mathrm{ml}$ before meals twice a day with Thalisadi Chooranam in after meals. No any decoctions, chooranam and other internal medicines.

\section{RESULT AND OBSERVATION}

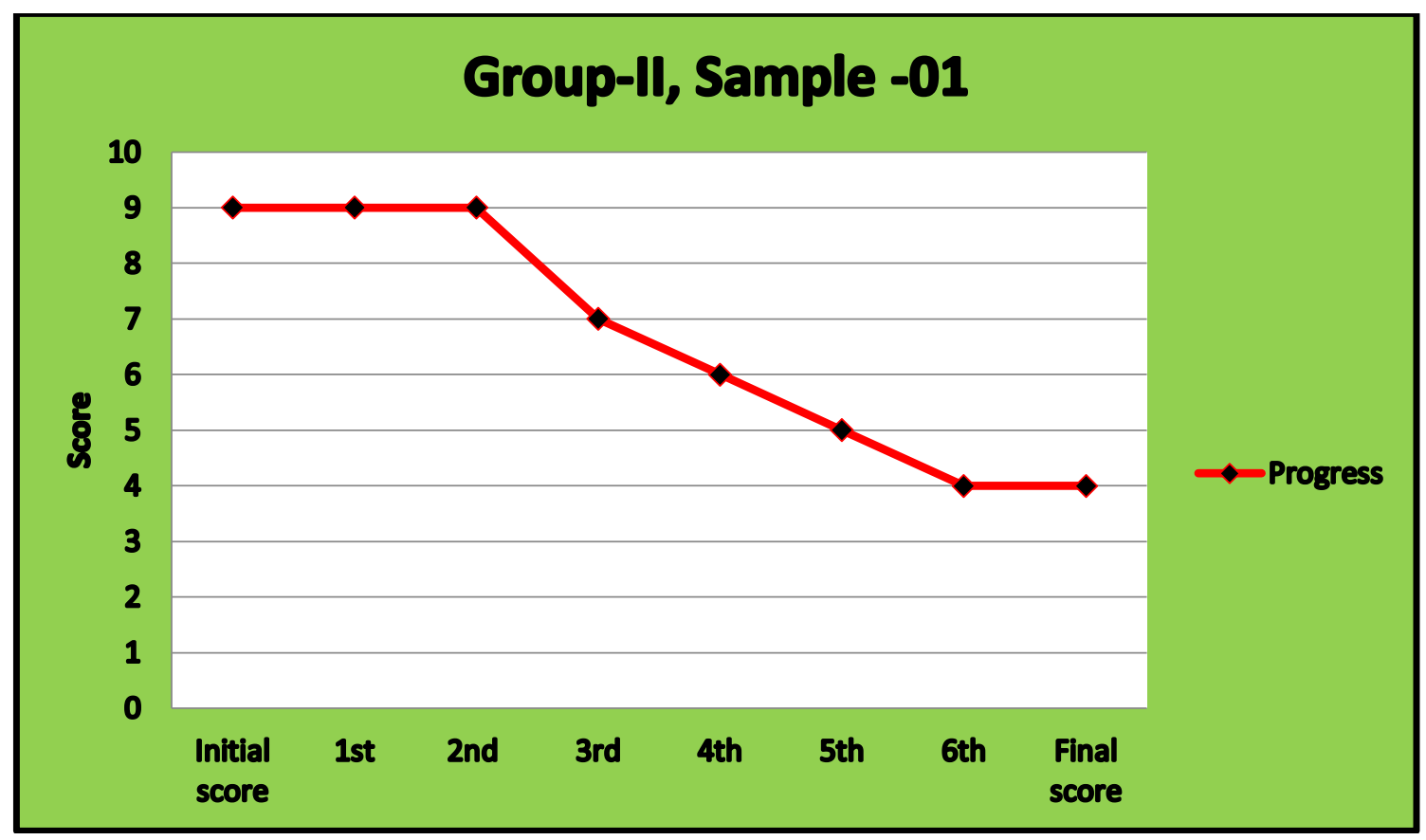

Chart 1: Every day follow-up the patients and their progress in each samples for research with grading score. 


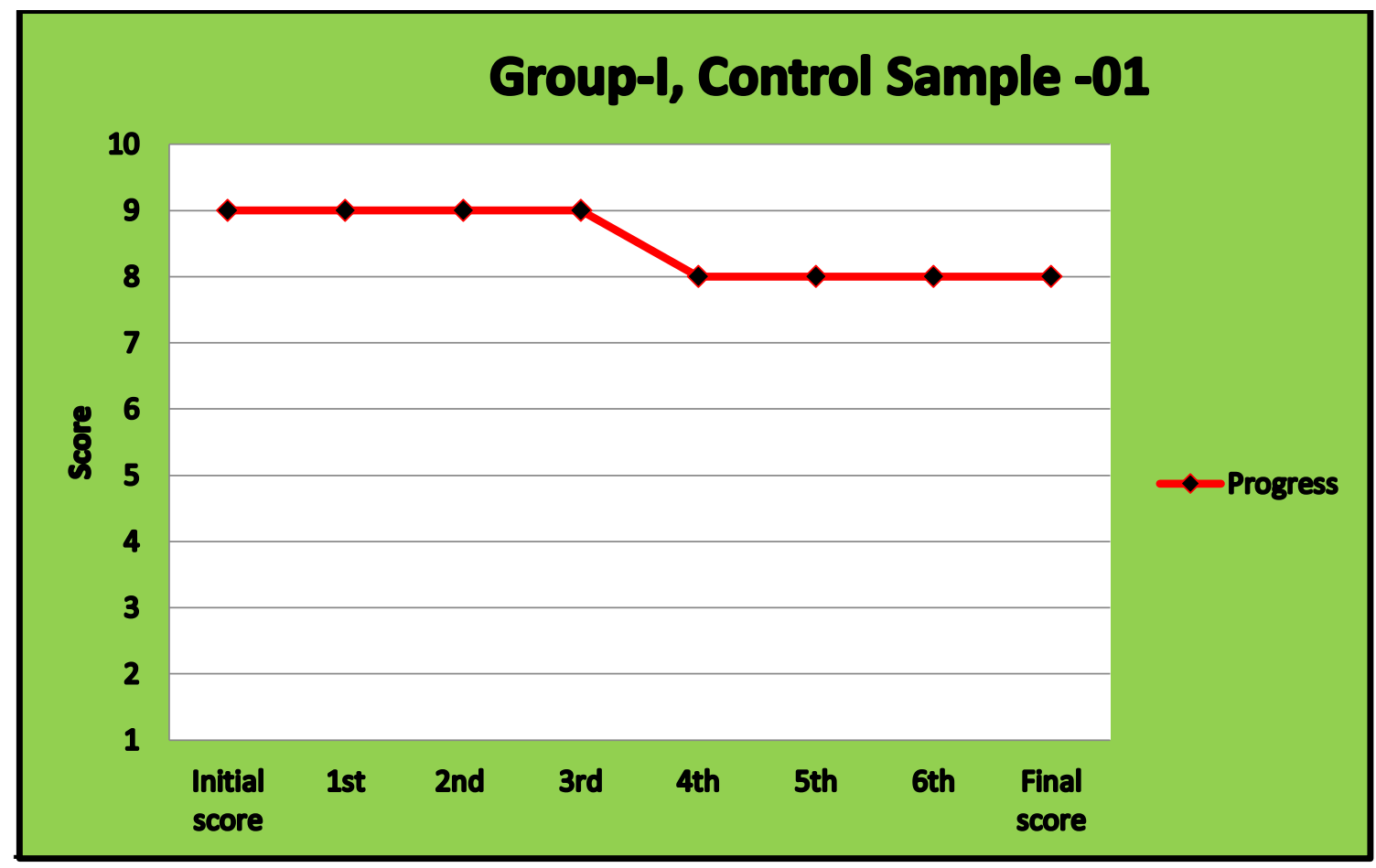

Chart 2: Every day follow-up the patients and their progress in each control samples for research with grading score.

\subsection{STATISTICAL ANALYSIS}

This research can analysis with qualitative statistical analysis not quantitative analysis therefore we analyzed symptoms in grading level not measurable therefore we used in qualitative way. We used Minitab 14 as statistical package. In a qualitative test or research Wilcoxon rank sum test (Mann-Whitney Test) is used to compare two independent samples.

\section{Symptom of Cough:}

Group-I \& Group-II $1^{\text {st }}$ Week (AFTER treatment) level of the samples.

The test is significant at 0.0001 (adjusted for ties)

Comparing the HT (Group-I), Research Decoction (Group-II) was shown Significant $(\mathrm{p}<0.05)$ reduction in symptom of cough.

One-month (04 Weeks) of treatment with research decoction significantly $(\mathrm{p}<0.05)$ change symptom of cough with the control group- hospital internal treatment (HT) (group-I).

\section{DISCUSSION AND CONCLUSION}

Finally, concluded effectiveness of research drugs - Sittamati Kudineer, one-month (04 Weeks) of treatment with research decoction significantly $(\mathrm{p}<0.05)$ change symptom of cough with the control group- hospital internal treatment (HT) (group-I). Sida cordifolia (S.cordifolia) is widely used for its medicinal applications. Presence of ephedrine has highlighted the utility of the plant. Therefore, this decoction is significant treatment of respiratory diseases especially in symptom of Cough. However, it is too early to say about benefit of the plant in treating obesity as negligible data has accumulated in term of its efficacy. Further the plant has hypoglycemic and appetite suppressant activity. Animal experiments however report hepato-protective effect of Sida cordifolia. 
Effect of "Sittamatti (Sida Cordifolia Linn.) Kudineer (Decoction)" in Respiratory Complaint - Cough APPENDICES
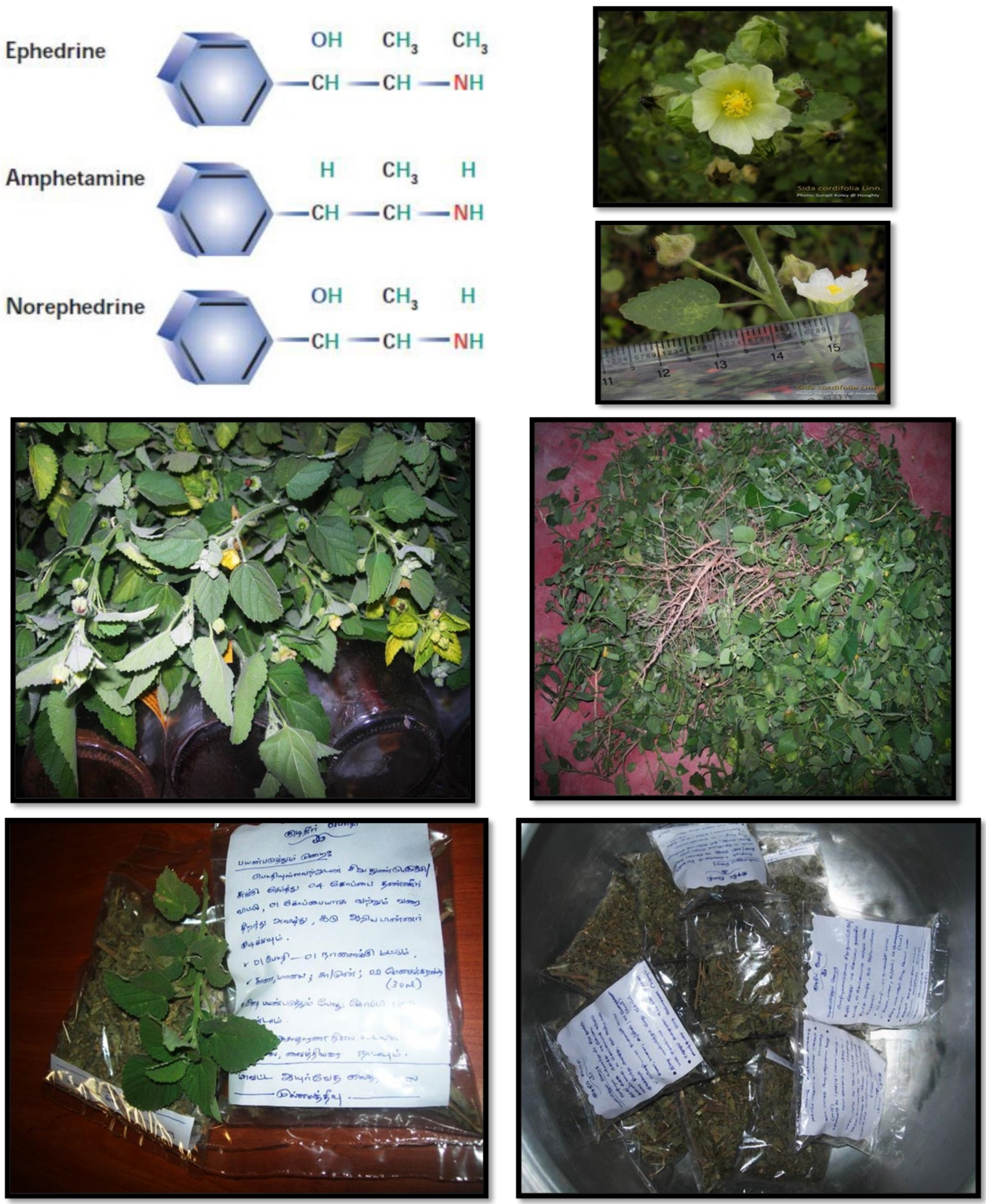
Dr. S. R. Pholtan Rajeev

\section{SOURCES OF FUNDING}

This research received no specific grant from any funding agency in the public, commercial, or not-for-profit sectors.

\section{CONFLICT OF INTEREST}

The author have declared that no competing interests exist.

\section{ACKNOWLEDGMENT}

I sincerely thank to Dr. (Mrs). S. Thurairatnam, Provincial Commissioner of Indigenous Medicine, Northern Province for grant permission to do research and clearances of ethics of clinical trial research. I thank to authentication of raw material (Sida cordifolia) by Dr. (Mrs). Vivian Sathiyaseelan, Senior Lecturer, In-Charge of Materia Medica, Unit of Siddha medicine, University of Jaffna. And Scientist (Pharmacognosy) Mrs. Sudeepa Sugathadasa In-Charge Botany section, BMARI, Nawinna, Sri Lanka. Finally thank to labourers of District Ayurvedic Hospital (DAH), Mullaitivu for collecting, preparation and packing of research decoction packs of research drug.

\section{REFERENCES}

[1] Agharkar S P. medicinal plants of Bombay presidenc.Pbl.scientific publishers. Jodhpur.India 1991; 194-195.

[2] Ankit Jain, Shreya Choubey, P.K.Singour, H. Rajak and R.S. Pawar Sida cordifolia (Linn) - An overview, Journal of Applied Pharmaceutical Science 01 (02);2011:23-31

[3] Annonyms. Compendium of Indian medicinal plants.: Vol 4. 1985 - 1989; 674-676.

[4] Annonyms. The Indian materia medica: With Ayurvedic, Unani and Home remedies. vol III ;1134-37

[5] Auddy B, Ferreira M, Blasina F, Lafon L, Arredondo F, Dajas F, Tripathi PC, Seal T, Mukherjee B. Screening of antioxidant activity of three Indian medicinal plants, traditionally used for management of neurodegenerative diseases. J Ethno pharmacol. 84.2003; 131-38.

[6] Balbach A. A Flora Medicinal na Medicina Domestica, 2 MVP, Itaquaquecetuba , 1978, 703

[7] Bhandari MM. Flora of Indian desert. Pbl. MPS Repros. Jodhpur. India; 1990.66-69

[8] Chopra Kanth VR, Diwan PV. Analgesic, anti-inflammatory and hypoglycemic activities of Sida cordifolia. Phytotherapy research. PTR 13 (1) 1999; 75-77.

[9] Chopra, R.N Indigenous Drugs of India, Academic Publishers, Calcutta, (1982).

[10] Cordell GA. Biodiversity and drug discovery: a symbiotic relationship, Photochemistry. 2000; 56: 463-480.

[11] Dawson JK, Eamshaw SM, Graham CS. Dangerous monoamine oxidase inhibitor interactions are still occurring in the 1990s. J Accid Emerg Med. 1995; 49-51.

[12] Dawson, J.K.; Eamshaw, S.M.; Graham, C.S. Dangerous monoamine oxidase inhibitor interactions are still occurring in the 1990s. J Accid Emerg Med. (1995),12 (1): 49-51.

[13] Diwan PV, Kulkarni DR. Anti-inammatory activity of nandrolone phenylpropionate. Indian J. Exp. Biol. 21.1983; 569- 573.

[14] Eddy N B, Leimbach D J. Synthetic analgesics. II. Dithienylbutenyl and dithienylbutilamines. J. Pharmacol. Exp. Ther.1953; 385

[15] Eric Wooltorton, Ephedra/ephedrine: cardiovascular and CNS effects CMAJ, 2002; 166 -176.

[16] Franco CIF, Morais LCSL, Quintans-Junior LJ, Almeida RN, Antoniolli AR. CNS pharmacological effects of the hydroalcoholic extract of Sida cordifolia L. leaves. J ethano. 2005; 98. 275-79.

[17] Franzotti EM, Santos CV, Rodrigues HM, Mourão RH, Andrade MR, Antoniolli AR. anti-inflammatory, analgesic activity and acute toxicity of sida cordifolia l. (malva-branca). J ethno pharmacol 72 (1-2) 2000; 273-78.

[18] Ghosal S, Chauhan RRPS, Mehta R. Alkaloids of Sida cordifolia. Phyto Chem. 1975; 14. 830-32.

[19] Ghosal, S.; Chauhan, R.R.P.S. and Mehta, R. (1975). Alkaloids of Sida cordifolia. Phytother Res. 14: 830-2.

[20] Haller CA, Benowitz NL. Adverse cardiovascular and central nervous system events associated with dietary supplements containing Ephedra alkaloids. NJEM. 2000; 34(3):1833-38. 
[21] Jenny M, Schwaiger W, Bernhard D, Wrulich OA, Cosaceanu D, Fuchs D, Ueberall F. Apoptosis induced by the Tibetan herbal remedy PADMA 28 in the T cell-derived lymphocytic leukemia cell line CEM-C7H2. J Crsino 4 .2005; 15 .

[22] Koman. Indian Materia Medica Gazette. Aug; 1921.

[23] Kumar RS, Mishra SH. Anti-inflammatory and hepatoprotective activities of Sida cordifolia Linn. Ind J Pharmacol .1997; 110-16.

[24] Mediros IA, Santos MRV, Nascimento NMS, Duarte JC. Cardiovascular effects of Sida cordifolia leave extract in rats. Fitoterapia.2005.

[25] Nayar and Chopra. Glossary Indian med: plants, PID. New Delhi; 1956.227.

[26] Pole, Sebastian.Ayurvedic medicine. Elsevier Health Sciences. 2006; 137.

[27] Ranajit K. Sutradhar AKM, Matior R, Mesbah UA, Sitesh CB. Phyto chem. letters, vol 1, issue 4.2008;179-82

[28] Rangari VD.Pharmacognosy and Phytochemistry. Part II; first edition; (2000) 274-275.

[29] Seigmund E, Cadmus R, Lu GA. method for evaluation of non- narcotic and narcotic analgesics. Proc. Soc. Exp. Biol. Med. 95.1957; 729.

[30] Silva RL, Melo GB, Melo VA, Antoniolli AR, Michellone PR, Zucoloto S, Picinato MA, Franco CF et al. Effect of the aqueous extract of Sida cordifolia on liver regeneration after partial hepatectomy. Acta cirurgica brasileira / Sociedade Brasileira para Desenvolvimento Pesquisa em Cirurgia 21 Suppl 1 2006; 37-9.

[31] Silva RS et al. Effect of the aqueous extract of Sida cordifolia on liver regeneration after partial hepatectomy. Acta Cir. 21(1) .2006; 77-79.

[32] Sumanth Meera and Mustafa S. S., Antistress and Adoptogenic Activity of Sida cordifolia Roots in Mice, Ind J Pharm Sci. 2009 May-Jun; 71(3): 323-324

[33] Sutradhar RK; A Rahman; MU Ahmad; BK Datta; SC Bachar; A Saha. Indian J Pharmacol., 2006, 38(3), 207-8.

[34] WHO monograph on selected medicinal plants. Vol. I and II; 1996, 97.

[35] Yogaratnakaram.madhyama kandam; 346-347. Yogaratnakaram.madhyama khandam;316-17 